\title{
The Role of Human Resources Management Towards Healthcare Providers Retention during Covid-19 Pandemic in Egypt
}

\author{
Ashraf Elsafty $^{1}$, \& Mohammad Ragheb ${ }^{1}$ \\ ${ }^{1}$ DBA., MBA., BSc., Adjunct Assistant Professor, ESLSCA University Egypt. \\ ${ }^{1}$ Doctoral Candidate, ESLSCA University Egypt, MBA, BSc., Egypt Care for Supplies, Founder and CEO, \\ Cairo, Egypt \\ Correspondence: Ashraf Elsafty, DBA., MBA., BSc., Adjunct Assistant Professor, ESLSCA University Egypt.
}

Received: June 24, 2021

doi:10.5539/ibr.v14n8p67
Accepted: July 16, 2021

Online Published: July 16, 2021

URL: https://doi.org/10.5539/ibr.v14n8p67

\begin{abstract}
HRM has a significant role in motivating the employees and ensuring that every employee is satisfied with the HR practices. Healthcare providers have been facing stress and depression especially in Egypt, due to COVID-19. In this country, the healthcare providers are looking for alternatives to achieve satisfaction as COVID-19 has affected their jobs, salaries, incentives, and bonuses. The past studies have focused on assessing the HRM's role in employee retention and satisfaction during the COVID-19 pandemic in Egypt. The past research discussed the impact of motivation, incentives, and rewards on the employees' motivation. This study focused on evaluating the role of HRM towards the healthcare providers' retention during COVID-19 in Egypt. This study relied on the quantitative approach for achieving the findings and conclusion. The sample size of the study involved 120 healthcare providers working in different hospitals. The results revealed that intrinsic motivation, rewards, incentives, monetary benefits, and non-monetary benefits have an essential role in maintaining the healthcare providers during COVID-19. It is concluded that HR can play a significant role in retaining key healthcare providers in COVID-19. The elements including intrinsic motivation, incentives, non-monetary, and monetary benefits can play a significant part in retaining healthcare providers. HR departments should focus on releasing salaries on time, providing specific bonuses, and providing incentives to healthcare providers whenever they perform at their best level.
\end{abstract}

Keywords: human resources, healthcare providers, retention, Covid-19, medical supplies, incentives, rewards

\section{Introduction}

Human resource management (HRM) tends to have a major role in managing the staff specifically in the case of COVID-19. There is a need to understand that HRM has a significant role in motivating the employees and ensuring that every employee is satisfied with the HR practices (Storey, 2016).

The healthcare providers panicked when the COVID-19 crisis occurred. In Egypt, the situation became worse, and the healthcare professionals had to work excessively to control the cases and provide quality care to the patients. The healthcare providers have not been completely satisfied with HRM practices during the COVID-19 crisis because they have been reduced in salaries, bonuses, rewards, and incentives. This aspect frustrated the healthcare providers and they were forced to switch jobs.

Elsafty \& Ragheb (2020) focused on assessing the HRM's role in employee retention and satisfaction during the COVID-19 pandemic in Egypt. Using the Business Anatomy Model '9 Elements' by Elsafty (2018/2020), developed and applied at several published studies, the Nine Elements Framework Model maps business anatomy to better identify and define the context under research study, exploring and assessing contextual analysis of research focus (Elsafty, A., Elsayed, \& Shaaban, 2020; Elsafty A., \& AlNawaly, 2020; Elsafty A., \& Ragheb, 2020; Elsafty, A., \& Abadir \& Sharawy, 2020; Elsafty, A., Elbouseery, I., \& Shaarawy, A., 2020; Elsafty, A., \& Tahon, A., 2021; Elsafty, A., \& Elzeftawy, A., 2021; Elsafty, A., \& Elshahed, M., 2021; Elsafty, A., \& Osman, M., 2021).

The past research discussed the motivation, which influences the employees' retention level, along with the research conducted in the same area. It is possible that healthcare professionals may not be satisfied with the retention programs and they start switching hospitals so that they get a good salary package and other incentives (Bratton \& Gold, 2017). It must be noted that in the case of COVID-19, it was a necessary element to ensure 
employee satisfaction because it is an urgent situation and requires active consideration from the stakeholders.

This study aims to evaluate the role of HRM towards the retention of healthcare providers during COVID-19 in the country of Egypt. It further focuses on potential strategies that can be employed by the HR professionals to manage and retain staff successfully. The core focus is to understand how HRM can have a significant impact on employee satisfaction and retention and how it can play a part in COVID-19.

\section{Problem Statement}

The healthcare industry in Egypt has already been suffering because of COVID-19 and there have been deaths that have shocked the nation. In such a case, the healthcare providers became worried due to their jobs and poor HRM practices. The healthcare providers have not been completely satisfied with the HRM practices as they were not provided with good salaries, incentives, rewards, and allowances that they deserve. It is essential to evaluate the role of HRM in ensuring retention of the healthcare providers specifically during the COVID-19 crisis. In this way, it can be possible to determine what potential strategies HR department can employ to retain healthcare providers especially in such a critical situation where millions of people have lost their lives.

\section{Research Question}

What is the role of HRM towards the retention of healthcare providers during the COVID-19 pandemic in Egypt?

\section{Research Objectives}

- To evaluate the role of HRM towards the retention of healthcare providers during COVID-19 in Egypt

- To assess the significance of HRM practices especially in COVID-19

- To recommend potential strategies that can be employed for retaining healthcare providers

\section{Literature Review}

Elsafty \& Ragheb (2020) focused on assessing the HRM's role in employee retention and satisfaction during the COVID-19 pandemic in Egypt. The past research discussed the motivation, which influences the employees' retention level, along with the research conducted in the same area. Some of the research studies have been involved in which techniques of the firms have been mentioned for curbing the negative influence of COVID-19. The researchers utilized the quantitative technique in which a total of 140 participants have been chosen as per the scale of "non-probability sampling". The variables under consideration are monetary benefits, non-monetary benefits, rewards, allowances, and bonuses. Correlation and descriptive statistics were considered as the statistical tools for achieving the findings. From the results, it is analyzed that the HR managers must play their part in maximization of the employees' satisfaction level, and their commitment towards work. HR professionals should focus on providing monetary and non-monetary benefits to the employees so that they work dedicatedly specifically in the case of COVID-19.

Rose \& Raja (2016) argued that in today's working environment, people tend to have distinct aspirations for fulfilling this staff's switch their jobs in a constant fashion. Hence, there is an issue of employee retention. The research was conducted for evaluating the role of distinct variables including organization commitment, job satisfaction, and HR practices in managing employee retention and satisfaction. The survey instrument including the Likert scale was utilized for gathering the data. The sample size of this research comprised of 180 staff of chosen IT companies in Bangalore. Correlation and One-way ANOVA were utilized for achieving the findings. The variables under consideration are HR practices, job satisfaction, salary packages, and incentives. The research revealed that job satisfaction and HR practices significantly impact organizational commitment and eventually the organization's commitment impact employee retention. The research recommends that firms must strive to possess good HR practices in the place and keep every employee satisfied. It may assist the firms to have committed staff in the organization and eventually it would focus on contributing to retaining the staff.

Mahal (2012) argued that globalization has not only assisted the firms to look for proficient staff; however, also to retain accomplished, talented, and expert employees. Thus, the core role of HR practices in fostering the staff's engagement, the organizational practices in the retention of employees, and the commitment of employees tend to be paramount. The core role of the research involved examining, interpreting, and evaluating the association between employee commitment and HR practices, and observing whether these tend to be negatively or positively correlated, as there are not sufficient research studies that evaluate whether there is a negative and positive association between employee retention and HR practices in the Indian economy. Around 100 staff from the Indian economy were considered. The HR practices and employee commitment were found to be positively correlated. The results further revealed that HR professionals should provide incentives, rewards, motivation, and bonuses to retain employees. 
Haque (2021) explained that the crisis of the COVID-19 pandemic tends to have posed a big challenge for the healthcare firms to explore techniques for dealing with their survival. The healthcare staff tends to be the frontline soldiers for fighting against the pandemic. Presently, there tends to be insufficient research related to COVID-19's conceptualization and its potential influence on the wellbeing of healthcare staff and their organizational sustainability. The findings highlighted that firms should focus on going beyond the strategic climate's application and must allow RL for protecting and maintaining organizational sustainability and employee well-being.

The HR manager tends to face certain challenges during the period of COVID-19; however, it tends to vary with their firm's location, industry, and size. Firms tend to be seeking alternate corporate techniques, including utilization of technology for supporting work-from-home or reviewing the costs for stretching the budget. Business-continuity planning and crisis management tend to remain the big challenges faced by HR during the outbreak of COVID-19. In this study, the researchers focused on analyzing distinct HR strategies followed by various firms during COVID-19. The variables that were considered by the researchers include concerns of employees, preventive measures, rewards, and employee communication. The list of techniques includes employee communications for increasing awareness, implementing preventive measures, managing the work arrangements, and addressing concerns of employees or workplace policies, manager-worker association, digitizing HR practices, and modifying the present welfare policies of staff.

\section{Methodology}

For the present study, a quantitative method was utilized for reaching the findings. Through this method, it was possible to perform the statistical analysis and avoid bias in the results. The questionnaire was utilized for collecting the responses and achieving the desired outcomes (Sanders et al., 2013). The questionnaire was based on the Likert-scale. The scale was from 1 (strongly agreed) to 5 (strongly disagreed). The quantitative research played a significant role in collecting data from a large sample size.

A major benefit of the quantitative method was that it assisted in including several questions about the topic (Sanders et al., 2013). The participants were able to understand the questions and just had to tick mark the answer, which made it easy. Through this method, it became possible to reach the findings and avoid discrepancies in the results.

\section{Proposed Framework}

Independent variables Dependent variable

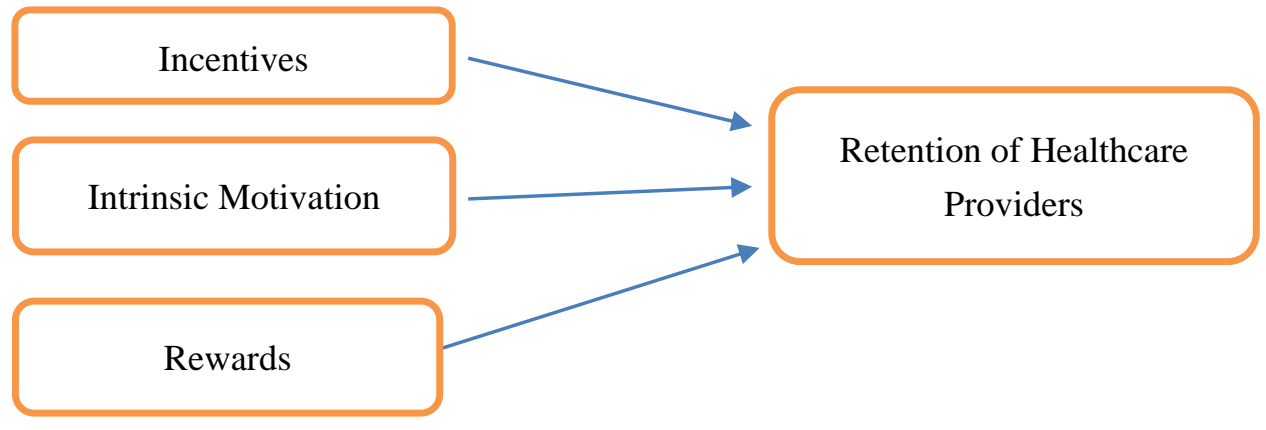

The conceptual model represents the independent and dependent variable. The independent variables are incentives, intrinsic motivation, and rewards. The dependent variable is the retention of healthcare providers.

\section{Research Philosophy}

For the present study, positivism philosophy had been utilized. In this philosophy, there are large samples and the sample is highly structured. Positivism plays a crucial role in understanding the topic in an objective manner (Bryman, 2016). The topic of the role of HR is a crucial one and positivism philosophy played a major role in exploring the topic in-depth.

One of the major benefits of this philosophy is that it assisted in conducting in-depth research and avoiding bias in the results (Bryman, 2016). Hence, this philosophy assisted in forming a definite conclusion and achieving the desired results.

\section{Research Approach}

For this study, a deductive approach was utilized. This approach tends to be concerned with the development of a 
hypothesis based on the present framework and then designing the research technique for testing the hypothesis (Bryman, 2016). This approach is utilized when there is already a present theory that can be verified or rejected. A major benefit of this approach was that it helped in explaining the causal associations between variables and concepts. There is an abundance of sources in this approach and limited time for completing the research study. Based on this approach, it was possible to test the hypothesis and theory. It can be argued that the deductive approach played a significant role in evaluating the role of human resources in the retention of healthcare providers during COVID-19.

\section{Sample Size}

The sample size of the study was 120 participants working in different hospitals. The sample comprised of 200.00 element of population, from which 120.000 were selected, so $90 \%$ true and $7 \%$ error was observed. The questionnaire was sent online to the respondents so that it was easy for them to fill it out online. Due to COVID restrictions, the primary data were collected online through e-mail.

\section{Secondary Research}

The secondary research was carried out for achieving the findings and outcomes. The secondary research played a significant role in creating a foundation for the research study (Chu \& Ke, 2017). The literature review was carried out to back the study findings and create a basis for the research. Through the literature review, it was possible to understand the role of HR in different firms in ensuring employee satisfaction specifically in the case of COVID-19.

The secondary research relied on past research articles, authentic websites, company websites, and government-published data (Chu \& Ke, 2017). Through the help of these data, it was possible to conduct the whole research study and reach the desired outcomes. Literature review played a major role in understanding and interpreting the opinions of different researchers and authors about the role of Human Resources, especially in the COVID-19 pandemic.

\section{Ethics}

Ethics was prioritized throughout the research study. When distributing the questionnaires, the participants were guided about all the questions and their importance in the study (Cascio \& Racine, 2018). The consent form was provided to the participants so that they had the option of withdrawing from the study at any time. The research was carried out online due to COVID-19, so all the questions were explained through emails and voice notes. In this way, there were minimal chances of errors or mistakes.

Ethics was also considered when writing the literature review and findings, using proper citations and credit have been given to the authors and researchers, so their work gets the due credit. There was no fabrication of the data or results, which is a positive aspect.

\section{Findings \& Results}

The results section focuses on the findings gained from the secondary information researched, and the primary data collected using questionnaire based on Likert-scale ( $1=$ strongly agree to $5=$ strongly disagree), integrated and generating the conclusions based on the inferential results gained from the statistical analysis.

\section{Responses}

Certain questions were included in the questionnaire. It is important to discuss the responses gained from the participants.

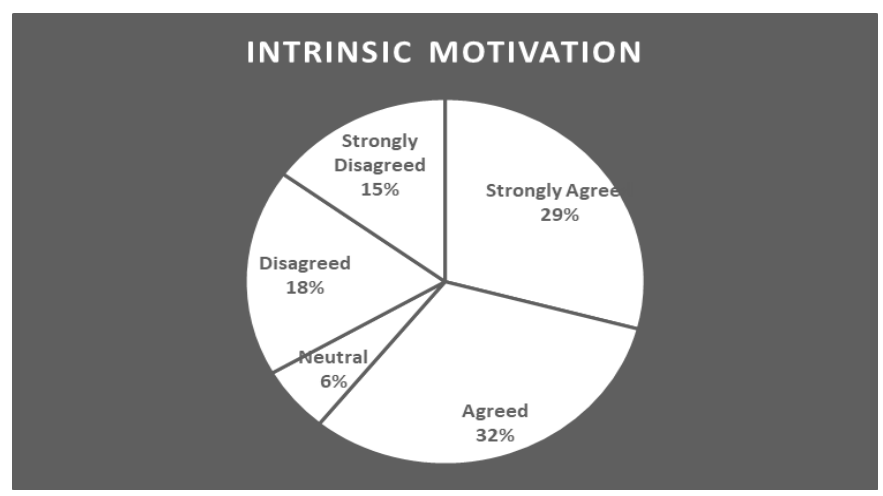

Figure 1. Intrinsic Motivation 
The above figure indicates the responses to the intrinsic motivation question. The majority of the participants (32\%) agreed that intrinsic motivation has a major role in retaining healthcare providers during COVID-19. Based on the analysis, it can be argued that healthcare providers perform at their optimum level when they receive intrinsic motivation from the HR professionals. In the case of COVID-19, this technique can work successfully for healthcare professionals as they have to provide care to critically ill patients.

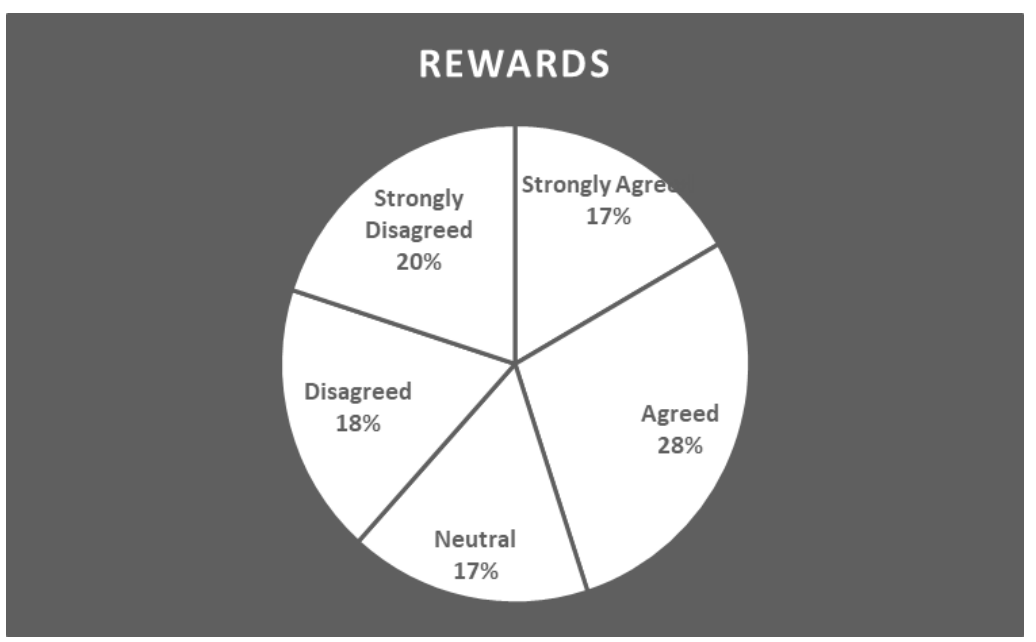

Figure 2. Rewards

One of the questions was that "rewards have a big role in the healthcare providers' retention during COVID-19 in Egypt". Most of the respondents (28\%) agreed that rewards and allowances work effectively in retaining healthcare providers. The analysis revealed that there are mixed responses ss some of the participants (18\%) disagreed with the statement. It can be argued that rewards may not be a big motivating factor for some of the employees.

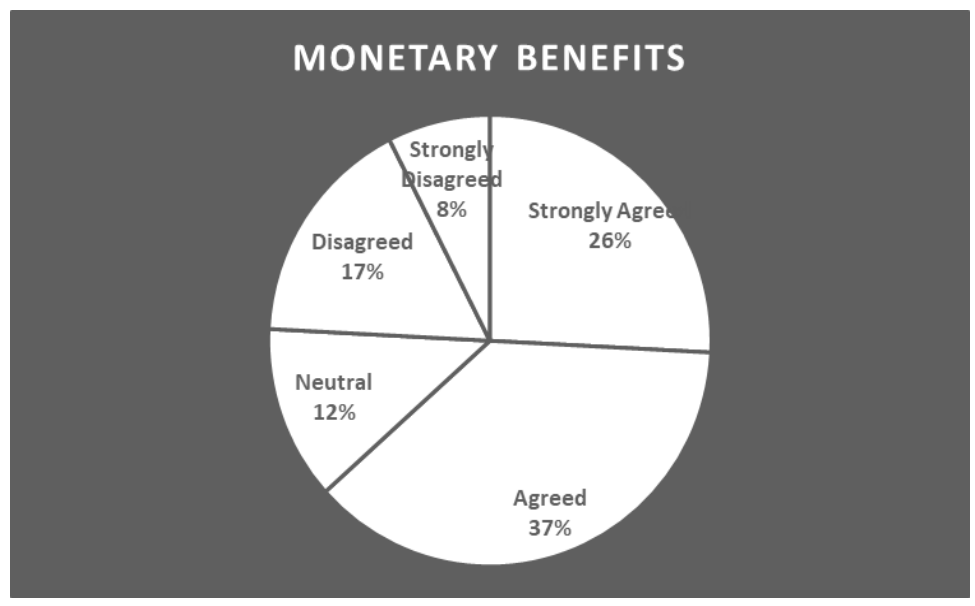

Figure 3. Monetary Benefits

A question was that whether monetary benefits help in the retention of healthcare providers in COVID-19. Most of the respondents (37\%) agreed with the statement. The responses helped in understanding that monetary benefits including bonuses, rewards, and salary increases are the major factors that motivate the healthcare providers to perform at their maximum level.

One of the questions was that whether rewards and incentives can help in retaining the healthcare providers during COVID-19. The majority of the respondents agreed with this statement. Based on the responses, it was analyzed that rewards and incentives are effective elements that can retain key employees specifically in the healthcare sector. The rewards may include an increase in salary and bonuses. The incentives may include petrol allowance, house allowance, and loan options. These strategies can play a major part in retaining healthcare 
professionals.

It is important to note that many people lost their jobs during the pandemic. In such a case, the healthcare professionals were already worried about the salary and other incentives. HR can play a major part by assuring healthcare providers that they would get their due credit and salaries on time.

\section{Descriptive Statistics}

\begin{tabular}{|l|c|c|c|}
\hline & $\begin{array}{l}\text { Intrinsic } \\
\text { Motivation }\end{array}$ & Incentives & Rewards \\
\hline Mean & 2.405 & 2.391 & 2.312 \\
\hline Standard Error & 0.079 & 0.083 & 0.080 \\
\hline Median & 2.424 & 2.593 & 2.608 \\
\hline Mode & \#N/A & \#N/A & \#N/A \\
\hline Standard Deviation & 0.86 & 0.91 & 0.87 \\
\hline Sample Variance & 0.74 & 0.83 & 0.76 \\
\hline Kurtosis & $(1.36)$ & $(1.29)$ & $(1.17)$ \\
\hline Skewness & 0.05 & $(0.10)$ & $0.08)$ \\
\hline Range & 2.97 & 2.90 & 2.95 \\
\hline Minimum & 1.02 & 1.09 & 1.01 \\
\hline Maximum & 3.98 & 3.99 & 3.96 \\
\hline Sum & 300.62 & 310.89 & 301.41 \\
\hline Count & 120 & 120 & 120 \\
\hline
\end{tabular}

The above table indicates the descriptive statistics. It is important to evaluate the mean responses gained from the participants. The analysis revealed that most of the participants agreed with the questions regarding intrinsic motivation, incentives, and rewards.

In the case of intrinsic motivation, the mean value is found to be 2.4 , which highlights that most of the participants supported the argument that intrinsic motivation can play a major part in retaining healthcare providers during COVID-19. The mean value for incentives was 2.39 , while for rewards, the value was 2.31 . The mean responses highlighted that most of the participants agreed with the statement.

\section{Inferential/Regression Analysis}

\section{Hypothesis}

\section{Hypothesis 1}

$\mathrm{H}_{01}$ : intrinsic motivation does not assist in retaining healthcare providers in COVID19

$\mathrm{H}_{\mathrm{A} 1}$ : intrinsic motivation helps in retaining healthcare providers in COVID19

\begin{tabular}{|l|l|}
\hline Regression Statistics \\
\hline Multiple R & 0.192914 \\
\hline R Square & 0.037216 \\
\hline Adjusted R Square & 0.029057 \\
\hline Standard Error & 0.856331 \\
\hline Observations & 120 \\
\hline
\end{tabular}

\begin{tabular}{|l|l|l|l|l|l|l|l|l|}
\hline ANOVA & & & & & & & & \\
\hline & $\mathrm{df}$ & SS & MS & F & Significance F & & & \\
\hline Regression & 1 & 3.344773 & 3.344773 & 4.561239 & 0.03477 & & & \\
\hline Residual & 118 & 86.52982 & 0.733304 & & & & & \\
\hline Total & 119 & 89.8746 & & & & & & \\
\hline & & & & & & & & \\
\hline & Coefficients & $\begin{array}{l}\text { Standard } \\
\text { Error }\end{array}$ & t Stat & P-value & Lower 95\% & $\begin{array}{l}\text { Upper } \\
95 \%\end{array}$ & $\begin{array}{l}\text { Lower } \\
95.0 \%\end{array}$ & $\begin{array}{l}\text { Upper } \\
95.0 \%\end{array}$ \\
\hline & 2.060279 & 0.240968 & 8.550028 & $5.18 \mathrm{E}-14$ & 1.583098 & 2.53746 & 1.583098 & 2.53746 \\
\hline $\begin{array}{l}\text { Intercept } \\
\text { Motinsic }\end{array}$ & 0.19432 & 0.090986 & 2.135706 & 0.03477 & 0.014142 & 0.374497 & 0.014142 & 0.374497 \\
\hline
\end{tabular}

The dependent variable was retention of healthcare providers and the independent variable was intrinsic 
motivation. The p-value is found to be 0.03 , which indicates that the null hypothesis should be rejected. It indicates that intrinsic motivation can play a vital role in retaining healthcare providers in the period of COVID-19. It further explains that intrinsic motivation has a significant association with the healthcare providers' retention.

\section{Hypothesis 2}

$\mathrm{H}_{02}$ : Incentives do not assist in retaining healthcare providers in COVID19

$\mathrm{H}_{\mathrm{A} 2}$ : Incentives help in retaining healthcare providers in COVID19

\begin{tabular}{|c|c|c|c|c|c|c|c|c|}
\hline \multicolumn{9}{|c|}{ Regression Statistics } \\
\hline Multiple R & 0.182914 & & & & & & & \\
\hline R Square & 0.047216 & & & & & & & \\
\hline $\begin{array}{ll}\text { Adjusted } & \mathrm{R} \\
\text { Square } & \end{array}$ & 0.039057 & & & & & & & \\
\hline Standard Error & 0.856331 & & & & & & & \\
\hline Observations & 120 & & & & & & & \\
\hline \multicolumn{9}{|l|}{ ANOVA } \\
\hline & $d f$ & $S S$ & MS & $F$ & $\begin{array}{l}\text { Significance } \\
F\end{array}$ & & & \\
\hline Regression & 1 & 3.344773 & 3.344773 & 4.561239 & 0.02877 & & & \\
\hline Residual & 118 & 86.52982 & 0.733304 & & & & & \\
\hline \multirow[t]{3}{*}{ Total } & 119 & 89.8746 & & & & & & \\
\hline & & & & & & & & \\
\hline & Coefficients & $\begin{array}{l}\text { Standard } \\
\text { Error }\end{array}$ & $t$ Stat & $P$-value & Lower $95 \%$ & $\begin{array}{l}\text { Upper } \\
95 \%\end{array}$ & $\begin{array}{l}\text { Lower } \\
95.0 \%\end{array}$ & $\begin{array}{l}\text { Upper } \\
95.0 \% \\
\end{array}$ \\
\hline Intercept & 2.060279 & 0.240968 & 8.550028 & $5.18 \mathrm{E}-14$ & 1.583098 & 2.53746 & 1.583098 & 2.53746 \\
\hline Incentives & 0.18432 & 0.090986 & 2.135706 & 0.03477 & 0.014142 & 0.374497 & 0.014142 & 0.374497 \\
\hline
\end{tabular}

The dependent variable was retention of healthcare providers and the independent variable was incentives. The p-value is found to be 0.02 , which indicates that the null hypothesis should be rejected. It indicates that incentives can play a vital role in retaining healthcare providers in the period of COVID-19.

\section{Hypothesis 3}

$\mathrm{H}_{03}$ : Rewards do not assist in retaining healthcare providers in COVID19

$\mathrm{H}_{\mathrm{A} 3}$ : Rewards can assist in retaining healthcare providers in COVID19

\begin{tabular}{|c|c|c|c|c|c|c|c|c|}
\hline \multicolumn{9}{|c|}{ SUMMARY OUTPUT } \\
\hline \multirow{2}{*}{\multicolumn{9}{|c|}{ Regression Statistics }} \\
\hline & & & & & & & & \\
\hline Multiple R & 0.202914 & & & & & & & \\
\hline R Square & 0.057216 & & & & & & & \\
\hline $\begin{array}{ll}\text { Adjusted } & \mathrm{R} \\
\text { Square } & \\
\end{array}$ & 0.049057 & & & & & & & \\
\hline $\begin{array}{l}\text { Standard } \\
\text { Error } \\
\end{array}$ & 0.856331 & & & & & & & \\
\hline Observations & 120 & & & & & & & \\
\hline \multicolumn{9}{|l|}{ ANOVA } \\
\hline & $d f$ & $S S$ & $M S$ & $F$ & $\begin{array}{l}\text { Significance } \\
F\end{array}$ & & & \\
\hline Regression & 1 & 3.344773 & 3.344773 & 4.561239 & 0.01125 & & & \\
\hline Residual & 118 & 86.52982 & 0.733304 & & & & & \\
\hline \multirow[t]{2}{*}{ Total } & 119 & 89.8746 & & & & & & \\
\hline & Coefficients & $\begin{array}{l}\text { Standard } \\
\text { Error }\end{array}$ & $t$ Stat & $P$-value & Lower 95\% & $\begin{array}{l}\text { Upper } \\
95 \%\end{array}$ & $\begin{array}{l}\text { Lower } \\
95.0 \%\end{array}$ & $\begin{array}{l}\text { Upper } \\
95.0 \% \\
\end{array}$ \\
\hline Intercept & 2.060279 & 0.240968 & 8.550028 & $5.18 \mathrm{E}-14$ & 1.583098 & 2.53746 & 1.583098 & 2.53746 \\
\hline Rewards & 0.18432 & 0.090986 & 2.135706 & 0.03477 & 0.014142 & 0.374497 & 0.014142 & 0.374497 \\
\hline
\end{tabular}


The dependent variable was retention of healthcare providers and the independent variable was rewards. The p-value is found to be 0.01 , which indicates that the null hypothesis should be rejected. It indicates that rewards can play a vital role in retaining healthcare providers in the period of COVID-19.

\section{Discussion}

The analysis helped in achieving a definite conclusion about the topic. Based on the results, it is concluded that HR can play a significant role in retaining key healthcare providers in COVID-19. The elements including intrinsic motivation, incentives, non-monetary, and monetary benefits can play a major part in the retention of healthcare providers.

The dependent variable was retention of healthcare providers and the independent variables included rewards, intrinsic motivation, and incentives. The hypothesis testing helped in concluding that all the three independent variables including rewards, intrinsic motivation, and incentives. The core focus was to evaluate the association between the variables. It is concluded that HR departments should have a strong focus on releasing salaries on time, providing certain bonuses, and providing incentives to healthcare providers whenever they perform at their best level. In this way, it can be possible to retain employees who work dedicatedly to fight the pandemic and saves lives.

\section{Conclusions}

The literature also supported the findings as different researchers supported the argument that incentives, rewards, salaries on time, allowances, and other non-monetary benefits can help in the retention of healthcare providers specifically in the time of COVID-19. It is further concluded that healthcare facilities should provide extra benefits to healthcare providers whenever they demonstrate quality in their work.

\section{Limitations}

A limitation of this research was that there was a limited duration to complete the study. There was insufficient time for gathering the responses and complete the writing process. Another limitation is that this study relied only on the quantitative method. Hence, the generated results can be considered unreliable up to a certain degree.

\section{Recommendations}

A major recommendation is that healthcare providers can be provided with high salary packages so they work at their optimum level to save lives (Abujaber \& Katsioloudes, 2015). Another suggestion is that healthcare providers should be guided that they would be provided with additional benefits if they get successful in treating the COVID-19 patients and ensure protection. One of the suggestions is that the healthcare providers can be given house allowances, loan allowances, and car allowances if they complete their benchmark (Abujaber \& Katsioloudes, 2015).

\section{Managerial Implication}

The recommendations can help in the retention of potential healthcare providers and may assist in avoiding discrepancies in the treatment of patients diagnosed with COVID-19. In a country like Egypt, it is vital to ensure that every patient is supplied with oxygen, ventilators, and other necessary supplies for battling COVID-19.

\section{References}

Abujaber, A., \& Katsioloudes, M. (2015). Impact of HR retention strategies in healthcare: The case of Qatar. Avicenna, 2015(1), 6. https://doi.org/10.5339/avi.2015.6

Bratton, J., \& Gold, J. (2017). Human resource management: theory and practice. Palgrave. https://doi.org/10.1057/978-1-137-58668-1

Bryman, A. (2016). Social research methods. Oxford university press.

Cascio, M. A., \& Racine, E. (2018). Person-oriented research ethics: integrating relational and everyday ethics in research. Accountability in research, 25(3), 170-197. https://doi.org/10.1080/08989621.2018.1442218

Chu, H., \& Ke, Q. (2017). Research methods: What's in the name? Library \& Information Science Research, 39(4), 284-294. https://doi.org/10.1016/j.lisr.2017.11.001

ElSafty, A. (2018). Business Research Methods. Egypt: Lecture Notes, Lecture One.

Elsafty, A. (2018). Lecture 2: Scientific Business Research Problem Definition [PowerPoint slides]. Retrieved from Maastricht School of Management, MBA Degree.

Elsafty, A. (2018). Lecture 2: Scientific Business Research Problem Definition [Lecture]. Retrieved from Maastricht School of Management, MBA Degree. 
Elsafty, A. (2020). DrAshrafElsafty Channel. Retrieved from https://www.youtube.com/watch?v=y-jDT2iOOhU\&list=PLKSWZdnzp8p3uFLLh2N8_d0W7ZmJDLMjW \&index $=42 \& \mathrm{t}=628 \mathrm{~s}$

Elsafty, A., \& AlNawaly, A. (2020). Role of Co-Working Spaces' Services in Entrepreneurs Growth in Upper Egypt, The Case of Step Co-Working Space. Business and Management Studies, 6(2).. https://doi.org/10.11114/bms.v6i2.4899

Elsafty, A., \& Elshahed, M. (2021). The Changes in Online Buying Intention as a Determinant of Behavior During COVID-19 Pandemic in the Ready-Made Garments Industry in Egypt. International Journal of Business and Management, 16(5), 1-24. https://doi.org/10.5539/ijbm.v16n5p1

Elsafty, A., \& Elzeftawy, A. (2021). The New Era of Digital Transformation and COVID-19 Effect on The Employment in Mobile Operators in Egypt. Business and Management Studies, 7(1), 1-21. https://doi.org/10.11114/bms.v7i1.5087

Elsafty, A., \& Osman, M. (2021). The Impact of COVID-19 on the Efficiency of Packing Lines in Pharmaceutical Manufacturing Sites in Egypt. International Journal of Business and Management, 16(7), 57-72. https://doi.org/10.5539/ijbm.v16n7p57

Elsafty, A., \& Ragheb, M. (2020). Role of Human Resource Management towards Employees Retention during Covid-19 Pandemic. Business and Management Studies, 6(2). https://doi.org/10.11114/bms.v6i2.4899

Elsafty, A., \& Tahon, A. (2020). Exploring Impact of Corporate Social Responsibility on Organizational Performance, the Case of Turkish Islamic Banks. Business and Management Studies, 7(1), 1-21. https://doi.org/10.11114/bms.v7i1.5087

Elsafty, A., Abadir, D., \& Shaarawy, A. (2020). How Does the Entrepreneurs' Financial, Human, Social and Psychological Capitals Impact Entrepreneur'S Success? Business and Management Studies, 6(3), 55-71. https://doi.org/10.11114/bms.v6i3.4980

Elsafty, A., Elbouseery, I., \& Shaarawy, A. (2020). Factors Affecting the Behavioral Intention to Use Standalone Electronic Personal Health Record Applications by Adults in Egypt. Business and Management Studies, 6(4), 14-36. https://doi.org/10.11114/bms.v6i4.5066

Elsafty, A., Elsayed, H., \& Shaaban, I. (2020). A Business Analysis Perspective for Engineering Education in Egypt. Journal of Education and Training Studies, 8(5), May 2020. ISSN 2324-805X E-ISSN 2324-8068. https://doi.org/10.11114/jets.v8i5.4721

Elsafty, A., Elsayed, H., \& Shaaban, I. (2020). Educating Engineering Students in Egypt: Recommendations for Improvement. International Journal of Higher Education. https://doi.org/10.5430/ijhe.v9n3p1

Elsafty, A., Elsayed, H., \& Shaaban, I. (2020). Journal of Education and Training Studies, 8(8). https://doi.org/10.11114/jets.v8i8.4901

Haque, A. (2021). The COVID-19 pandemic and the role of responsible leadership in health care: thinking beyond employee well-being and organisational sustainability. Leadership in Health Services. https://doi.org/10.1108/LHS-09-2020-0071

Mahal, P. K. (2012). HR Practices as Determinants of Organizational Commitment and Employee Retention. IUP Journal of Management Research, 11(4).

Rose, S., \& Raja, K. G. (2016). ROLE OF HR PRACTICES, JOB SATISFACTION, AND ORGANIZATION COMMITMENT IN EMPLOYEE RETENTION. CLEAR International Journal of Research in Commerce \& Management, 7(10).

Sanders, K., Cogin, J. A., \& Bainbridge, H. T. (Eds.). (2013). Research methods for human resource management. Routledge. https://doi.org/10.4324/9781315852300

Storey, J. (2016). Human resource management. Edward Elgar Publishing Limited. 


\section{Appendix}

\section{Questionnaire}

\begin{tabular}{|c|c|c|c|c|c|}
\hline \multirow{2}{*}{$\begin{array}{l}\text { Intrinsic motivation has a significant role in retaining healthcare providers } \\
\text { in COVID-19 }\end{array}$} & $\mathbf{S A}$ & $\mathbf{A}$ & $\mathbf{N}$ & D & DA \\
\hline & & & & & \\
\hline \multicolumn{6}{|l|}{$\begin{array}{l}\text { Incentives have a significant role in retaining healthcare providers in } \\
\text { COVID-19 }\end{array}$} \\
\hline \multicolumn{6}{|l|}{$\begin{array}{l}\text { Rewards have a significant role in retaining healthcare providers in } \\
\text { COVID-19. }\end{array}$} \\
\hline \multicolumn{6}{|l|}{$\begin{array}{l}\text { Extra-curricular activities have an essential role in retaining healthcare } \\
\text { providers. }\end{array}$} \\
\hline \multicolumn{6}{|l|}{$\begin{array}{l}\text { HR functions can assist in the retention of hardworking healthcare } \\
\text { providers. }\end{array}$} \\
\hline \multicolumn{6}{|l|}{$\begin{array}{l}\text { HR professionals can prepare proper policies that provide financial relief } \\
\text { to healthcare provider during COVID-19 }\end{array}$} \\
\hline \multicolumn{6}{|l|}{ COVID-19 resulted in the unemployment of various healthcare providers. } \\
\hline \multicolumn{6}{|l|}{$\begin{array}{l}\text { HR can provide additional benefits to healthcare providers for ensuring } \\
\text { their satisfaction. }\end{array}$} \\
\hline $\begin{array}{l}\text { Payroll should be revised from time to time for retaining healthcare } \\
\text { providers. }\end{array}$ & & & & & \\
\hline
\end{tabular}

\section{Copyrights}

Copyright for this article is retained by the author(s), with first publication rights granted to the journal.

This is an open-access article distributed under the terms and conditions of the Creative Commons Attribution license (http://creativecommons.org/licenses/by/4.0/). 